Małgorzata Baran-Łucarz

Uniwersytet Wrocławski

\title{
PODEJŚCIE STUDENTÓW FILOLOGII ANGIELSKIEJ DO REFLEKSJI W NAUCE WYMOWY
}

\section{Attitudes of English philology students towards reflection in pronunciation learning}

This paper aims to report attitudes of extramural students of the Department of English Studies, University of Wrocław, towards reflection which was introduced into a course of phonetics and into individual practice of pronunciation at home. The article opens with a brief presentation of the concept of reflection, a discussion of its importance in teaching foreign languages (FLS) and an overview of studies on the use of reflection in FL pronunciation teaching. The research design and the techniques used to develop reflection in the students in this study are then described. From the perspective of many learners involved in this research introducing reflection into pronunciation learning had several positive effects: it helped learners set goals and made them aware of effective learning strategies. It also aided them in self-evaluation, in understanding the emotions accompanying the learning of FL pronunciation, and in finding ways of dealing with these. However, it was found that many students were reluctant to have reflection introduced into the learning process. This was mainly due to lack of time and to students' belief that reflection does not bring any positive results. Finally, the author suggests that the ability to reflect on one's learning is difficult and dependent on individual predisposition, and that it requires special training.

Keywords: reflection, pronunciation learning, students' attitudes, retrospection, diary, survey

Słowa kluczowe: refleksja, uczenie się wymowy, podejście studentów, retrospekcja, dzienniczek, ankieta 


\section{Wprowadzenie}

Wertenbroch i Nabeth (2000) tłumaczą, że człowiek uczy się poprzez trzy główne procesy, tj. (1) mniej lub bardziej świadome obserwowanie i wchłanianie nowych informacji z zewnątrz za pomocą różnych zmysłów, (2) poprzez doświadczenie (czynny udział w procesie poznawczym) oraz (3) interakcję społeczną. Takie wyjaśnienie procesu uczenia się, choć szerokie, jest jednak niekompletne i wymaga uzupełnienia. Jak podkreślał bowiem John Dewey już w 1933 roku, opierając się na przemyśleniach myślicieli takich jak Arystoteles, Platon czy Konfucjusz, uczenie się odbywa się przede wszystkim poprzez refleksję nad wcześniejszymi doświadczeniami, przeżyciami i doznaniami (Farrell, 2007).

Choć o wadze refleksji w nauczaniu i uczeniu się mówi się od ponad 80 lat, to jednak faktyczne zastosowanie refleksji w dydaktyce jest wciąż stosunkowo nowym trendem (Stanley, 1998). Ponadto, mimo, iż uznaje się fakt pozytywnego wpływu refleksji na wyniki uczenia się, to obiektywnych badań jednogłośnie potwierdzających tę tezę jest niewiele.

Czym dokładniej jest refleksja? Według Dewey’a (1933), refleksja to myślenie i sposób rozwiązywania zadań i problemów, który polega na szukaniu i tworzeniu powiązań (cech wspólnych, różnic) między wiedzą i doświadczeniami, a szczególnie na tworzeniu związków miedzy nowymi i wcześniejszymi przemyśleniami. Refleksyjnego ucznia charakteryzuje pełna samoświadomość przy analizie własnych działań, prowadzenie przemyśleń nad przyczynami doświadczonych zdarzeń, odpowiedzialność za konsekwencje swoich wcześniejszych działań oraz otwartość na różnorodne rozwiązania danego problemu i gotowość ich zastosowania w przyszłości. W oparciu o analizę wcześniejszych doświadczeń, potrafi on i chce podejmować decyzje na temat dalszych działań (Dewey, 1933 w Farrell, 2008; Dewey, 1938; Schön, 1991).

\section{Refleksja w uczenie się wymowy języka obcego}

Współcześni glottodydaktycy jednogłośnie głoszą, iż warunkiem sukcesu w opanowaniu języka obcego jest konieczność aktywnego i w pełni świadomego zaangażowania się ucznia $w$ proces dydaktyczny (np. Pennington, 1992; Little, 2002). Uczący się języka obcego, któremu zależy na osiągnięciu sukcesu, musi być współodpowiedzialny za swój postęp i stawać się z czasem coraz bardziej autonomiczny, poprzez poznanie swoich słabych i mocnych stron, swojego stylu poznawczego, najbardziej efektywnych strategii uczenia się języka obcego, stawianie jasnych długo i krótkoterminowych celów językowych oraz poprzez przejmowanie konkretnych inicjatyw w uczeniu się. 
Jednak, jak wspomniano wyżej, autonomiczne uczenie się jest możliwe i efektywne, jeśli nauka jest procesem w pełni świadomym. W rozwijaniu tejże świadomości niezbędna jest refleksja (Pennington, 1992). Little (2002) tłumaczy, iż refleksja jest jednym z etapów uczenia się, przez który uczący musi przejść, by stać się autonomicznym uczniem. Obecnie jednym z najbardziej popularnych narzędzi rozwijających refleksyjność u uczących się języka obcego jest portfolio językowe. Innym dobrze znanym, choć rzadziej stosowanym, instrumentem do rozwijania refleksyjności jest dzienniczek.

Wprowadzanie refleksji do nauczania wymowy języka obcego związane jest najczęściej z określaniem przez uczących się celów uczenia się wymowy (np. preferowanego modelu czy poziomu poprawności w wymowie) oraz $z$ dokonywaniem samoceny, tj. próbą identyfikowania przez uczących się konkretnych aspektów swojej wymowy wymagających korekty (Pawlak, 2006; Nowacka, 2006). Jednak większość badań prowadzonych w zakresie refleksji towarzyszącej nabywaniu wymowy języka obcego dotyczy stosowania strategii uczenia się wymowy (np. Peterson, 2000; Bukowski, 2004; Pawlak, 2010; Całka, 2011; Rokoszewska, 2012). Najczęściej wskazują one, które strategie wykorzystywane są chętniej i częściej przez uczniów oraz które z nich prowadzą do lub związane są z poprawniejszą wymową (np. Rokoszewska, 2012).

Jak pokazują najnowsze badania, refleksyjność może być z powodzeniem wspomagana poprzez dzienniczki. Studenci biorący udział w badaniu Szyszki (w druku), którzy prowadzili zapiski w dzienniczkach na temat swoich doświadczeń związanych z uczeniem się fonetyki, zapewniają o ich ważnej roli w rozwijaniu refleksyjności oraz o ich pozytywnym wpływie na rozumienie istoty uczenia się wymowy i na identyfikowanie efektywnych dla nich strategii ćwiczenia wymowy. W eksperymencie prowadzonym przez Kennedy et al. (2013) dzienniczki pisane w parach pomiędzy uczestnikami kursu fonetyki również zwiększyły poziom świadomości fonologicznej uczących się. Ponadto, stwierdzono istotny związek miedzy refleksjami jakościowymi pisanymi przez studentów a rzeczywistym postępem w wymowie zaobserwowanym u tychże uczniów.

\section{Badanie}

Do nauczanego kursu fonetyki próbowałam wprowadzić elementy refleksji. Decyzja ta wynikała z przekonania o prawdziwości i istotności pewnych założeń. Po pierwsze, przyjęłam, iż poprawa wymowy, szczególnie u uczących się po okresie krytycznym, jest najczęściej procesem wymagającym systematycznego wysiłku, tj. dużo pracy własnej. Ta natomiast, aby była bardziej efektywna, powinna być poprzedzona jasno wytyczonymi celami oraz znalezieniem 
najbardziej efektywnych dla danego uczącego się strategii pracy nad wymową. Po drugie, uznałam za kluczowy fakt, że ćwiczenie wymowy zazwyczaj obarczone jest wysokim ładunkiem emocjonalnym. Potwierdzają to chociażby badania wstępne nad konstruktem jakim jest lęk związany z uczeniem się wymowy (phonetics/pronunciation learning anxiety), ukazujące bardzo ważną rolę samooceny, samowizerunku (pronunciation self-image) oraz obaw przed negatywną oceną innych w opanowaniu wymowy języka obcego (BaranŁucarz, 2013a). Jak dowodzą liczne badanie nad lękiem językowym (np. Phillips, 1992; Spielman i Radnofsky, 2001; Piechurska-Kuciel, 2008), negatywne emocje towarzyszące uczeniu się języka obcego są silnym, jeśli nie najsilniejszym wyznacznikiem sukcesu w opanowaniu języka obcego (Maclntyre, 1999). Wprowadzenie elementu refleksji do nauki wymowy wydawało mi się być niezbędne nie tylko dlatego, że mogłaby ona uczynić ten proces bardziej świadomym, celowym i autonomicznym, ale również, a może przede wszystkim, dlatego, że najprawdopodobniej pomogłaby uczącym się lepiej poznać i rozumieć własne emocje towarzyszące ćwiczeniu wymowy w klasie i nauczyć się je kontrolować oraz pokonywać ewentualny dyskomfort czy lęk odczuwany na tychże zajęciach. Czy jednak studenci będą chętni do włączenia refleksji w proces uczenia się wymowy? Czy dostrzegą korzyści wynikające z refleksyjnego podejścia do uczenia się tego aspektu języka obcego?

Głównym celem niniejszego artykułu jest podzielenie się obserwacjami wynikającymi z próby wprowadzenia refleksji do nauczania wymowy na kursie fonetycznym. Zaprezentowane badanie zostało zaplanowane i przeprowadzone, aby odpowiedzieć na dwa podstawowe pytania:

a. Jakie jest podejście studentów filologii angielskiej do włączenia refleksji w proces uczenia się wymowy?

b. Jakie są opinie studentów na temat efektów wprowadzania elementów refleksji do nauki wymowy?

Pomimo ograniczonej liczby studentów uczestniczących w badaniu i braku zastosowania statystycznej analizy danych, możliwe będzie zaobserwowanie pewnych tendencji i odpowiedzi na kolejne pytanie:

c. Czy podejście do refleksji ma związek z poziomem wymowy, metakompetencją fonologiczną, umiejętnością samooceny, autonomią lub motywacją studentów do osiągnięcia wysokiego poziomu wymowy?

\subsection{Podmioty badawcze}

W badaniu wzięły udział dwie grupy zaocznych studiów pierwszego roku filologii angielskiej w Uniwersytecie Wrocławskim, składające się w sumie 
z 26 osób, o średnim wieku 22 lata ${ }^{1}$. Wszyscy obligatoryjnie uczestniczyli w kursie fonetycznym, trwającym dwa semestry, każdy po 15 spotkań liczących 90 minut. Przed rozpoczęciem nauki na wyższej uczelni większość z podmiotów badawczych (85\%) uczyła się języka angielskiego w szkole podstawowej, gimnazjum oraz liceum i dodatkowo uczestniczyła w zajęciach pozalekcyjnych, tj. w kursach językowych czy korepetycjach. Jedna osoba uczyła się języka angielskiego samodzielnie dopóki nie zaczęła kursu językowego na innym kierunku, przed rozpoczęciem nauki na filologii angielskiej. 24 osoby zdały rozszerzoną maturę zaraz przed dostaniem się na studia; 2 pozostałych studentów podchodziło do matury 5 i 8 lat wcześniej. Mimo, że teoretycznie wszyscy reprezentowali poziom co najmniej B2, diagnoza przeprowadzona przed kursem fonetyki pokazała, iż ich poziom poprawności wymowy był na ogół niski. Charakteryzowała się ona typowymi błędami popełnianymi przez Polaków w zakresie segmentów i prozodii oraz nieprawidłową wymową wielu na co dzień używanych wyrazów, np. computer, development, area, abroad, law, Warsaw, foreign, accurate. Studenci mieli problemy ze wskazaniem aspektów swojej wymowy, które według nich wymagają szczególnej pracy, co mogłoby świadczyć o ich niskiej kompetencji fonologicznej. Warto podkreślić, iż większość studentów deklarowała (bardzo) wysoką motywację do uczenia się wymowy, tj. 81\% chciało zbliżyć się do poziomu rodzimego użytkownika języka angielskiego, 15\% określiło swój poziom motywacji jako wysoki, zaś 1 osoba oceniła swoją motywację na niskim poziomie. 2 studentów spędziło dłuższy czas w Wielkiej Brytanii (4 miesiące lub rok), 8 osób odbyło krótkie (od 2-tygodniowych do 2-miesięcznych) wizyty w jednym z krajów anglojęzycznych, zaś 15 słuchaczy nie miało do tej pory sposobności do wyjazdu za granicę.

Badanie opisane $w$ tej pracy trwało przez cały drugi semestr nauki, gdyż dopiero od drugiego semestru wprowadzono do kursu fonetyki elementy refleksji. Na tę decyzję miało wpływ kilka czynników, jak chociażby niski poziom metakompetencji fonologicznej w pierwszym semestrze, obawa przed zbytnim obciążeniem studentów rozpoczynających naukę wymowy, konieczność poznania przez nich różnych strategii ćwiczenia wymowy, czy problemy z samooceną wymowy.

\subsection{Kurs fonetyki}

Głównym celem opisywanego kursu była korekta wymowy studentów w zakresie segmentów, wybranych suprasegmentaliów (np. akcentu wyrazowego i rytmu) oraz aspektów mowy łączonej (np. form słabych, upodob-

\footnotetext{
${ }^{1}$ Serdeczne podziękowania studentom uczestniczącym w badaniu.
} 
nień, elizji) poprzez szereg zadań poprawiających percepcję, ćwiczenia usprawniające pracę artykulatorów oraz dużą ilość ćwiczeń kontrolowanych (powtarzanie i czytanie słów, zdań, dialogów indywidualnie, w parach, mniejszych grupach i z całą klasą) pomagających w wykształcaniu prawidłowych nawyków wymowy. $Z$ uwagi na ten fakt bardziej uzasadnione wydaje się określenie kurs wymowy niż kurs fonetyki. Należy jednak dodać, że studenci nie mieli osobnego kursu teoretycznego z fonetyki czy fonologii. W związku z powyższym, drugim celem kursu było podniesienie metakompetencji fonetycznej i fonologicznej słuchaczy, poprzez np. wprowadzanie podstawowej terminologii (np. nazwy artykulatorów), określanie sposobu, miejsca artykulacji i cech segmentów angielskich w odniesieniu do cech podobnych polskich dźwięków, podniesienie wiedzy studentów w zakresie typowych cech modelu RP (Received Pronunciation) i GA (General American) oraz nauczenie studentów sprawnego posługiwania się alfabetem fonetycznym (IPA - International Phonetic Alphabet). Oprócz głównych zadań, na zajęciach realizowane były również bardzo istotne cele dodatkowe, tj. uświadomienie studentom konieczności systematycznej pracy nad wymową poza kursem, pokazanie licznych strategii ćwiczenia wymowy i przekonanie o łatwej dostępności wielu pomocy i materiałów dydaktycznych do pracy własnej nad wymową (szczególnie pomocy multimedialnych), czy wreszcie rozwijanie refleksyjności i autonomii studentów.

\subsection{Techniki stymulujące refleksję}

Aby rozwinąć u studentów refleksyjność w zakresie uczenia się wymowy posłużyłam się kilkoma narzędziami. Pierwszym z nich była retrospekcja, której wyniki pisane były anonimowo przez wszystkich studentów pod koniec zajęć fonetyki przez okres dwóch miesięcy. Do zadania studenta należało określenie swojego poziomu dyskomfortu/lęku/zażenowania towarzyszącego wykonywaniu konkretnych ćwiczeń podczas kończącej się lekcji (w skali od 0 do 6 punktów) oraz dodanie komentarza na temat samopoczucia, możliwych przyczyn przeżywanych stanów emocjonalnych oraz sugestii na temat sposobów redukowania negatywnych odczuć wywołanych podczas wykonywania danego ćwiczenia lub na konkretnym etapie lekcji. Głównym celem retrospekcji była pomoc studentom $\mathrm{w}$ otworzeniu się i przyznaniu przed sobą samym do emocji towarzyszących ćwiczeniu wymowy, a tym samym $w$ rozumieniu przyczyn ewentualnego niskiego poziomu zaangażowania w ćwiczenie, a co za tym idzie - słabszych rezultatów. Co najważniejsze, przemyślenia te miały prowadzić do poszukiwania sposobów na radzanie sobie z negatywnymi uczuciami i na pokonanie lęku. 
W rozwijaniu refleksji miały też pomóc dzienniczki otwarte, do których prowadzenia w domu byli zachęcani wszyscy studenci, zapewniani o korzyściach mogących wypływać z tej formy refleksji. Początkowo dzienniczki mogły mieć formę dowolną, np. mniej lub bardziej zorganizowane myśli, tabele, notatki w formie elektronicznej lub pisane odręcznie, nagrania audio na telefon, w języku polskim lub angielskim. Sugerowano, by dzienniczki uzupełniano przynajmniej raz w tygodniu, najlepiej każdorazowo po ćwiczeniu wymowy w domu. Proponowano, aby zapisywano w nich obserwowane trudności w wymowie zauważone na konkretnych zajęciach fonetyki lub podczas samodzielnej pracy nad wymową, przemyślenia na temat przyczyn tychże trudności, cele wytyczone na najbliższą przyszłość, wyniki stosowania różnych strategii podczas ćwiczenia wymowy poza klasą, emocje towarzyszące uczeniu się wymowy oraz jakiekolwiek inne przemyślenia, które uważają za warte zarejestrowania.

Jednak, aby nie pozbawiać dzienniczka jednej z jego typowych cech, tj. prawa do jego prywatności, dzienniczek nie był ani obowiązkowy ani poddawany formalnej ocenie. Podkreślano jednak, że istnieje możliwość podzielenia się swoimi refleksjami z nauczycielem. Tłumaczono, że mogłoby to zaowocować zaoferowaniem konkretnej pomocy przez nauczyciela w zakresie dalszego ćwiczenia wymowy oraz wpłynąć pozytywnie na końcową ocenę semestralną.

Po 6 tygodniach słabego zainteresowania studentów prowadzeniem dzienniczków otwartych, zastąpiono je dzienniczkami z proponowanq strukturq i dokładnq instrukcjq w kwestii częstotliwości i rodzaju ćwiczeń do wykonywania w domu. Tym razem przemyślenia miały być zorganizowane w formie tabeli, z kolumnami o następujących nagłówkach: 'opis ćwiczenia', 'moja wymowa (zauważalny postęp bądź jego brak)', 'emocje (np. radość, satysfakcja, wściekłość, lęk, poirytowanie) towarzyszące ćwiczeniu wymowy i ich przyczyny', 'plany dalszej pracy', 'inne uwagi'. Tym razem dzienniczki traktowane były jako obowiązkowe zadanie domowe, przez co musiały stracić swoją anonimowość. Ich brak zaznaczany był przez nauczyciela jako nieodrobiona praca domowa.

Wreszcie refleksje prowadzone w trakcie nauki uzupełnione zostały refleksją końcową, wieńczącą kurs fonetyki. Tym razem zastosowano anonimowq ankietę, składającą się z 15 pytań. W 7 z nich zastosowano skalę Likerta, po których następowały pytania otwarte dotyczące uzasadnienia wybranej odpowiedzi. Natomiast pozostałe 8 pozycji było w formie typowych pytań otwartych. W ankiecie pytano o następujące kwestie:

- stopień z fonetyki uzyskany w poprzednim semestrze,

- chęć zbliżenia wymowy do poziomu rodzimego użytkownika języka,

- motywację do uzyskania jak najwyższej oceny z fonetyki,

- poziom wymowy po kursie fonetyki i zaobserwowany postęp w wymowie,

- częstotliwość i sposób ćwiczenia wymowy w domu, 
- aspekty wymagające dalszych ćwiczeń,

- najbardziej efektywne dla studentów strategie ćwiczenia wymowy,

- podejście do autonomii w uczeniu się wymowy,

- opinie na temat refleksji pisanych podczas zajęć fonetyki w domu oraz ewentualne powody ich niepisania.

\subsection{Prezentacja i dyskusja wyników}

\subsubsection{Retrospekcja}

Podejście studentów do wypełniania tabel retrospekcji były różne, tj. od entuzjastycznego przez obojętne lub nawet niechętne. Niektórzy dzielili się bardzo szczegółowymi obserwacjami, inni ograniczali się do określenia swojego poziomu dyskomfortu przy poszczególnych etapach lekcji i ćwiczeniach. Pamiętając reakcje studentów na niektóre ćwiczenia i porównując je z komentarzami w retrospekcjach zaryzykowałabym stwierdzenie, że nie wszyscy potrafili lub chcieli otworzyć się przed samymi sobą i/lub nauczycielem i przyznać się do negatywnych odczuć, które zdawały się paraliżować wielu z nich w trakcie wykonywania niektórych ćwiczeń. Oto przykłady paru zapisków przepisanych z wypełnionych przez studentów tabel w retrospekcjach:

- Gimnastyka artykulatorów - poziom lęku/dyskomfortu: '2'; 'Bardzo przydatne ćwiczenie. Wydaje mi się, że lepiej mi się czytało i mówiło po jego zastosowaniu.'

- Gimnastyka artykulatorów - '6';'To było przestraszne!'

- Czytanie dialogu po polsku-angielsku - '4';'Odczuwałem dyskomfort, ponieważ bałem się, że brzmię śmiesznie.'

- Czytanie dialogu po polsku-angielsku - '3';'Gdy jest wesoło, jest dobrze (-; ciekawa sprawa.'

- Identyfikacja miejsca artykulacji - '6'; 'Zażenowanie na maxa spowodowane nieradzeniem sobie z zadaniem.'

- Czytanie tekstu na głos - '3'; 'Nie spodobało mi się to ćwiczenie, bo mam z tym problemy, ale jak poćwiczę $w$ domu, to myślę, ze poziom stresu się zmniejszy.'

Poznanie opinii studentów na temat tego, które ćwiczenia generują wysoki poziom dyskomfortu i dlaczego było cenne również dla nauczyciela prowadzącego kurs fonetyki. Doprowadziło ono do utworzenia rankingu ćwiczeń generujących poczucie lęku (Baran-Łucarz, 2013b) oraz zaowocowato konkretnymi zmianami $w$ działaniach w klasie (np. częstsze ćwiczenia w parach i grupach, ograniczenie poprawy błędów na forum całej grupy). 
Końcowym etapem tej formy refleksji była krótka sesja dyskusyjna, której celem było uzmysłowienie studentom, że wielu z nich czuje podobne napięcie oraz próba przekonania ich o naturalności owej reakcji. Wreszcie dyskusję wieńczyło wspólne dzielenie się doświadczeniem oraz pomysłami dotyczącymi sposobów radzenia sobie z emocjami. Za najbardziej efektywny sposób uznano systematyczne ćwiczenie wymowy w domu.

\subsubsection{Dzienniczki}

Przez okres 6 tygodni 5 osób kilkakrotnie podzieliło się z nauczycielem swoimi refleksjami zapisanymi w dzienniczkach otwartych. Większość refleksji napisanych było odręcznie; dwoje studentów przesyłało zapiski jako załączniki do maili. Najczęstszymi tematami poruszanymi w dzienniczkach były sposoby ćwiczenia wymowy w domu, emocje towarzyszące pracy nad wymową oraz uwagi na temat kursu fonetyki. Niektórzy wspominali też o zauważalnych efektach pracy nad wymową. Brakowało natomiast bezpośrednich wzmianek o tym, co studenci planują dalej ćwiczyć i w jaki sposób. W swoich refleksjach autorzy wyraźnie próbowali nawiązać bliższy kontakt z nauczycielem, prosząc o nadzór pracy i informację zwrotną do zapisków w dzienniczkach. Poniżej prezentuję przykłady zapisków z dwóch dzienniczków.

„Zacząłem się nagrywać po angielsku na Youtube parę dni temu. Chodzi o 'gaming footage', który każdy może odsłuchać i dodać swój komentarz. Poprosiłem ludzi, żeby pisali mi co myślą o moim angielskim i podzielili się poradami ze mną. W ten sposób nie tylko świetnie się bawię, ale i ćwiczę m.in. wymowę. $\mathrm{O}$ dziwo, nawet się przy tym nie stresuję. Ćwiczenie w ten sposób pomaga mi się przełamać, bo muszę przyznać, że przed dostaniem się na studia strasznie się wstydziłem mówić po angielsku. Chyba właśnie z powodu wymowy. Fajnie by było, gdyby Pani posłuchała moich nagrań (tu podany adres) i podzieliła się ze mną swoimi spostrzeżeniami.

Zaraz po nagraniu się odezwał się jakiś koleś z Anglii. Strasznie się zdziwiłem, że tak szybko ktoś odpisał. Jeszcze bardziej się zdziwiłem, kiedy gościu stwierdził, że muszę ćwiczyć dźwięk 'th', bo mi jeszcze nie wychodzi. Jakby był na naszych zajęciach i słyszał Pani uwagi skierowane do mnie! Na początku byłem na niego wściekły, ale potem wdzięczny, ze zwrócił mi uwagę. W końcu o to mi chodziło!"

„Lekcje fonetyki odgrywają dużą rolę w mojej nauce j. angielskiego. Wcześniej nie zdawałam sobie sprawy, ze nawet najprostsze słowa jak 'cat' czy 'taxi' wymawiam źle. Zauważyłam ostatnio, że kiedy oglądam filmy i seriale po angielsku, często powtarzam pojedyncze słówka za aktorami. Bardziej zwracam teraz uwagę na ich wymowę niż wcześniej. Literkę [?], którą najbardziej lubię, a z którą 
miałam [w czasie przeszłym?] największe problemy jest 'th'. Moje współlokatorki śmiały się ze mnie, kiedy chodziłam po mieszkaniu i mówiłam sobie wyraz, w którym występuje ten dźwięk. Przynajmniej dzięki mnie zauważyły też, że same źle go wymawiały $:$. Nie jestem sama do końca pewna, czy go dobrze wymawiam. Moją ogólną refleksją jest to, że nauczyciele języka angielskiego powinni kłaść większy nacisk na wymowę swoich uczniów."

Po wprowadzeniu obowiązku prowadzenia dzienniczka oraz narzuceniu jego formy i rodzaju ćwiczeń do wykonywania w domu, liczba osób piszących refleksje zwiększyła się do 10 (38\%). Studenci zdawali się skupiać bardziej na ocenie postępu oraz na świadomym planowaniu dalszej pracy. Rzadziej można było zaobserwować bezpośrednie odnoszenie się bezpośrednie do nauczyciela, natomiast wyraźniej rysowały się bardziej autonomiczne decyzje autorów refleksji. Poniżej prezentuję przykład zapisu jednego z dzienniczków (patrz Ilustracja 1).

\begin{tabular}{|c|c|c|c|c|}
\hline $\begin{array}{l}\text { Opis } \\
\text { ćwiczenia }\end{array}$ & $\begin{array}{l}\text { Moja wymowa } \\
\text { (zmiany, poprawa, } \\
\text { brak poprawy) }\end{array}$ & $\begin{array}{l}\text { Emocje (radość, } \\
\text { satysfakcja, wście- } \\
\text { kłość, lęk, poiry- } \\
\text { towanie, itd.) }\end{array}$ & Plany dalszej pracy & Inne uwagi \\
\hline $\begin{array}{l}\text { Pon. i środa } \\
\text { Ćwiczenia 'th' } \\
\text { tak jak suge- } \\
\text { rowano }\end{array}$ & $\begin{array}{l}\text { Wydaje mi się, że po } \\
\text { każdej serii powtórzeń } \\
\text { jest lepiej. }\end{array}$ & (;) & $\begin{array}{l}\text { Będę próbował } \\
\text { dalej tak ćwiczyć, } \\
\text { aż wymowa tych } \\
\text { dźwięków stanie } \\
\text { się bardziej natu- } \\
\text { ralna. }\end{array}$ & $\begin{array}{l}\text { Pomaga mi też } \\
\text { śpiewanie piose- } \\
\text { nek. Jak śpiewam } \\
\text { zwracam szczegól- } \\
\text { nq uwagę na } \\
\text { słowa z 'th'. } \\
\text { Chyba śpiewam te } \\
\text { słowa poprawniej. }\end{array}$ \\
\hline $\begin{array}{l}\text { Czwartek } \\
\text { Ćwiczenie } \\
\text { / S / }\end{array}$ & $\begin{array}{l}\text { Poprawa jest, ale póki co, } \\
\text { muszę się mocno kontro- } \\
\text { lować... }\end{array}$ & $\begin{array}{l}\text { Lubię czytać po } \\
\text { polsku-angielsku. } \\
\text { Wydaje mi się, że } \\
\text { to ćwiczenie na- } \\
\text { prawdę mi poma- } \\
\text { ga. }\end{array}$ & $\begin{array}{l}\text { Będę dalej ćwiczył } \\
\text { udajqc native } \\
\text { speakera z Anglii. }\end{array}$ & $\begin{array}{l}\text { Chyba wkrótce } \\
\text { będę mógł grać } \\
\text { w filmach Anglika } \\
\text {-). }\end{array}$ \\
\hline
\end{tabular}

Ilustracja 1. Przykład zapisu z dzienniczka.

\subsubsection{Ankieta końcowa}

Anonimową ankietę wypełniło 20 studentów. Jak się okazało, prawie wszyscy (poza 1 osobą) potrafili ocenić swój poziom wymowy po kursie fonetyki. 5 osób (20\%) uznało swój poziom za bardzo wysoki, 10 (38\%) - za wysoki, 3 (11,5\%) za niski, zaś 1 osoba określiła swój poziom jako bardzo niski. 7 osób (47\%), które oceniły swój poziom wymowy jako wysoki bądź bardzo wysoki pisały refleksje 
w domu. Pozostali studenci, tj. ci, którzy ocenili swoją wymowę na poziomie niskim lub bardzo niskim oraz osoba, która nie potrafiła dokonać samooceny, nie napisali ani jednej refleksji oprócz retrospekcji w klasie. Warto dodać, iż 6 na 7 studentów, którzy na koniec semestru pierwszego otrzymali ocenę dobry plus lub bardzo dobry włączali refleksję w ćwiczenie wymowy w domu. Byli to studenci nie tylko najbardziej obowiązkowi, ale i tacy, którzy reprezentowali dobrą metakompetencję fonetyczną i fonologiczną oraz wysoki poziom wymowy.

Jeśli chodzi o możliwy związek między motywacją uczących się a ich podejściem do refleksji, wyniki prezentują się następująco: tylko 7 studentów na 17 (41\%), którym zależało na jak najwyższej ocenie z fonetyki przynosiło nauczycielowi dzienniczki wypełniane w domu; podobnie, tylko 7 na 18 osób (39\%), które deklarowało, że chciało osiągnąć poziom zbliżony do rodzimego użytkownika języka, włączało refleksje w naukę wymowy poza kursem. Nie wydaje się też, aby dane zebrane $w$ tym badaniu wskazywały na istotny związek między podejściem do pisania refleksji a autonomią uczących się. Chociaż $70 \%$ ankietowanych (zdecydowanie) zgodziło się z twierdzeniem 'Lubię sam/a kierować swojg praca nad wymowq', to tylko połowa z nich pokusiła się o pisanie refleksyjnych dzienniczków. Można jednak podać w wątpliwość szczerość udzielonych na to pytanie odpowiedzi. Niektórzy mogli zgodzić się z powyższym stwierdzeniem uznając, że takiej odpowiedzi się od nich oczekuje.

Ciekawe różnice $w$ danych jakościowych można zaobserwować w przypadku odpowiedzi na pytanie 'Jakie aspekty wymowy wymagaja dalszych ćwiczeń?'. Osoby, które nie pisały refleksji, udzielały bardzo ogólnych odpowiedzi (np. 'różne dźwięki'), zaś wszyscy studenci, którzy włączyli refleksję w uczenie się wymowy podały dokładniej jakie aspekty (segmenty lub suprasegmenty) wymagają dalszych ćwiczeń. Podobnie, chociaż każdy ankietowany potrafił podać sposoby ćwiczenia wymowy, które są według niego/niej najbardziej efektywne, to jednak odpowiedzi studentów refleksyjnych różniły się od odpowiedzi pozostałych osób. Strategie podawane przez osoby, które nie pisały refleksji, ograniczały się do paru typowych sposobów ćwiczenia wymowy, tj. 'powtarzanie/mówienie na głos', 'czytanie transkrypcji', 'czytanie dialogów'. Tymczasem strategie podane przez osoby piszące refleksje były znacznie bogatsze. Oprócz sposobów wspomnianych powyżej pojawiły się następujące strategie:

- 'nagrania z koleżanką i wzajemne odsłuchiwanie się'

- ' 'przesłanie nagrania nauczycielowi; próba wprowadzenie sugerowanych zmian'

- 'powtarzanie przed lustrem'

- 'czytanie transkrybowanych tekstów'

- 'shadowing'

- 'śpiewanie kontrolowane" 
- 'mówienie z przesadą'

- 'nagrywanie się na Youtube i rozmowa z osobami na temat mojej wymowy'

- 'świadome słuchanie radia i robienie notatek kiedy usłyszę cos nowego'

- 'praca z programem 'Say it Right'

- 'sprawdzanie i zapisywanie w moim prywatnym słowniczku wymowy nowych słów'

Wśród odpowiedzi na pytanie 'Co sqdzisz na temat refleksji pisanych w trakcie zajęć?' pojawiło się parę negatywnych, takich jak: 'Wiem, że miały pomóc naszemu wykładowcy, ale nie chciało mi się ich pisać', 'Zbyt częste', 'Irytujqce'. Jednak większość studentów dostrzegła korzyści wynikające z pisania retrospekcji, pisząc, że 'były ciekawe' i pozwoliły im 'pomyśleć i powtórzyć co było na zajęciach i otworzyć się na innych', 'zrozumieć jak ważne sq zajęcia z fonetyki i jak bardzo poprawna wymowa ułatwia komunikację', 'zrozumieć co jeszcze muszę się nauczyć', 'zastanowić się nad moimi odczuciami' $i$ 'wyrazić swoje emocje.'

Choć tak niewiele osób wprowadziło refleksję do nauki wymowy poza klasą, to ci którzy to uczynili uznali ją za cenną. Oto niektóre odpowiedzi udzielone na pytanie: 'Co dało Ci pisanie dzienniczków?' przez studentów, którzy pisali refleksje w domu:

- 'Cieszyła mnie możliwość podzielenie się z kimś tym, co czułem.'

- 'Dzięki nim zaczęłam myśleć o fonetyce jako o przyjemnym i miłym przedmiocie. Przestałam stresować się na zajęciach.'

- 'Mogłam się zastanowić i zaplanować nad czym muszę popracować.'

- 'Dzięki refleksjom miałam możliwość obiektywnie spojrzeć na moją pracę nad wymową oraz zauważyć postęp. Ponadto, mogłam jasno dać do zrozumienia nauczycielowi jakiej pomocy od niego oczekuję i rozwiać ewentualne wątpliwości.'

- 'Jestem bardziej świadomy swoich błędów i sposobu jak je poprawić.'

- 'Głębsze zastanowienie się nad swoją wymową.'

Ostatnie pytanie skierowane było do osób, które nie pisały dzienniczków. Dotyczyło ono uzasadnienia ich decyzji. Studenci podawali następujące wyjaśnienia: 'Były zbędne', 'Nie sq mi potrzebne. W niczym by mi nie pomogły', 'Nie wiem czemu miały służyć'. Jednak najczęstszym argumentem był 'Brak czasu'. Ankietowani pisali: 'Zabierajq dużo czasu', 'Nie miałem zbytnio czasu', 'Nie było na to czasu', 'Odkładałem to ciqgle na później', 'Nie miałem czasu. Niestety muszę godzić studia z pracq.' Warto dodać, iż mimo, że zajęcia odbywały się dwa dni w tygodniu, tylko około $20 \%$ podmiotów badawczych pracowało bądź studiowało na innym kierunku. Można więc przypuszczać, że są też inne powody, dla których osoby deklarujące chęć osiągnięcia wysokiego poziomu wymowy nie włączyły refleksję w jej naukę. Jednym z uzasadnień może być przyzwyczajenie do bycia prowadzonym przez na- 
uczyciela i niechęć do wzięcia odpowiedzialności za postęp (lub jego brak) w wymowie. Można też przypuszczać, że osoby obserwowane w tym badaniu nie ćwiczyły wymowy w domu, a tym samym uznały, że nie miały niczego do przemyślenia i opisania. Istnieje też prawdopodobieństwo, że ich poziom motywacji do zbliżenia się do poziomu rodzimych użytkowników języka był jednak niższy od deklarowanego, a zaznaczone odpowiedzi wynikały jedynie z chęci zadowolenia nauczyciela fonetyki, bądź z uznania, że taki poziom motywacji powinni reprezentować. W próbie zrozumienia reakcji studentów może pomóc też fakt, że refleksja jest trudna. Jak tłumaczy Stanley (Arnold, 1999: 111), „Refleksja jest skomplikowanym procesem kognitywnym i emocjonalnym, którego nauczenie się wymaga czasu i ćwiczeń" (tłumaczenie własne). Stanley podkreśla również (ibidem), że w snuciu refleksji bardzo istotną rolę odgrywają emocje, które albo pomagają albo stanowią przeszkodę. Równocześnie warto przypomnieć, że wymowa języka obcego i proces uczenia się tego aspektu są wyjątkowo mocno naładowane emocjami, częste negatywnymi. Przyznanie się przed sobą do przeżywania takich uczuć, tj. zażenowania, lęku, złości z powodu braku zauważalnego postępu, bądź niższego poziomu od kolegów może być trudne i zniechęcać do refleksji.

Na koniec warto odnieść się do słów Copeland i in. (1993: 348), którzy podkreślają, iż „ludzie różnią się w zakresie możliwości, umiejętności i skłonności do refleksji" (tłumaczenie własne). Wśród różnic indywidualnych, które mogą kształtować zdolność i gotowość uczących się do podejmowania refleksji mogą być niektóre wymiary osobowości (np. otwartość, ego bariery, samoświadomość, ekstrawersja/introwersja), styl poznawczy (np. stopień niezależności od pola danych oraz tolerancyjności na nierealistyczne doświadczenia), czy styl atrybucyjny. Dalsze badania w tym kierunku wydają się niezbędne, aby wiedzieć jak pomóc rozwijać refleksyjność u uczących się języka obcego.

\section{Podsumowanie}

Z perspektywy studentów, wprowadzenie refleksji do nauki wymowy przynosi wiele korzyści, tj. czyni ona uczącego się bardziej świadomym celów, które chce osiągnąć, strategii uczenia się, które są dla niego najbardziej efektywne i pomaga w samoocenie oraz zrozumieniu i opanowaniu emocji towarzyszących ćwiczeniu wymowy. Jak się jednak okazuje, wiele osób podchodzi do refleksji niechętnie, tłumacząc, że ich zdaniem refleksja nie przynosi żadnych korzyści oraz że nie mają czasu na prowadzenie refleksji w domu. Można jednak zaryzykować stwierdzenie, że zaskakująco niskie zainteresowanie studentów refleksją w tym badaniu wynikać może również z tego, że reflek- 
sja jest trudna i wymaga stosownego treningu, zaś umiejętność prowadzenia refleksji zależy od indywidualnych predyspozycji uczącego się.

Dane uzyskane w tym badaniu nie potwierdziły jakoby wysoka motywacja była wystarczającym motorem wiodącym ku refleksji. Dokładniejsza analiza sylwetek refleksyjnych studentów, którzy systematycznie prowadzili dzienniczki, pozwala podsumować, iż są to osoby lepiej znające niedoskonałości w swojej wymowie, mające bogatszy repertuar strategii ćwiczenia wymowy oraz posiadające wyższy poziom wymowy i meta kompetencji fonologicznej niż osoby stroniące od refleksji. Owe obserwacje nie pozwalają jednak określić, czy związki między wyżej wymienionymi zmiennymi a podejściem do refleksji są statystycznie istotne i jak są silne. Ponadto, wyniki nie upoważniają do stwierdzenia, iż wymienione pozytywne cechy refleksyjnych podmiotów badawczych, wynikają z wprowadzenia przez nich refleksji do uczenia się wymowy. Przeprowadzenie badania np. typu eksperymentalnego z grupą kontrolną oraz eksperymentalną mogłyby rozwiać wątpliwości i wzbogacić naszą wiedzę na ten temat.

\section{BIBLIOGRAFIA}

Baran-Łucarz, M. 2013a. „Phonetics learning anxiety - results of a preliminary study". Research in Language 11.1: 57-79. DOI: 10.2478/v10015-012-0005-9.

Baran-Łucarz, M. 2013b. „Anxiety in a FL pronunciation course” (w:) Proceedings of PTLC2013, Papers from the Phonetics Teaching and Learning Conference, London, 8-10 2013 (red. J. Przedlacka, J. Maidment i M. Ashby). London: Chandler House: 19-22.

Bukowski, D. 2004. „On the training of metacognitive and socio-affective strategies some implications for teaching and learning English phonetics" (w:) Dydaktyka fonetyki języka obcego w Polsce (red. W. Sobkowiak i E. Waniek-Klimczak). Konin: Wydawnictwo Państwowej Wyższej Szkoły Zawodowej w Koninie: 2004. 20-27.

Całka, A. 2011. „Pronunciation learning strategies - identification and classification” (w:) Speaking and instructed foreign language acquisition (red. M. Pawlak, E. Waniek-Klimczak i J. Majer). Clevedon: Multilingual Matters: 149-168.

Copeland, W.D., Birmingham, C., De La Cruz, E. i Lewin, B. 1993. „The reflective practitioner in teaching: Toward a research agenda". Teaching and Teacher Education 9: 347-359.

Dewey, J. 1933. How we think. A restatement of the relation of reflective thinking to the educative process. Boston: D. C. Heath.

Dewey, J. 1938. Experience and education. New York: Macmillan/Collier Books.

Farrell, T. S. C. 2008. Reflective language teaching: From research to practice. London: Continuum Press.

Kennedy, S., Blanchet, J. i Trofimovich, P. 2013. „L2 learners' speech after French phonetics teaching" (w:) Proceedings of PTLC 2013, Papers from the Phonet- 
ics Teaching and Learning Conference, London, 8-10 2013 (red. J. Przedlacka, J. Maidment i M. Ashby). London: Chandler House: 43-49.

Little, D. 2002. „The European Language Portfolio: structure, origins, implementation and challenges". Language Teaching 35.3: 182-9.

Maclntyre, P. D. 1999. „Language anxiety: A review of the research for language teachers" (w:) Affect in foreign language and second language learning. A practical guide to creating a low-anxiety classroom atmosphere (red. D. J. Young). Boston: McGraw-Hill: 24-45.

Nowacka, M. 2006. „To hear ourselves as others hear us - evaluation and self- evaluation of the pronunciation of English department graduates" (w:) Dydaktyka fonetyki języka obcego. Neofilologia (red. W. Sobkowiak i E. Waniek-Klimczak). Płock: Zeszyty Naukowe Państwowej Wyższej Szkoły Zawodowej w Płocku: 107-130.

Pawlak, M. 2006. „The place of learner autonomy in pronunciation instruction” (w:) Dydaktyka fonetyki języka obcego. Neofilologia (red. W. Sobkowiak i E. WaniekKlimczak). Płock: Zeszyty Naukowe Państwowej Wyższej Szkoły Zawodowej w Płocku: 131-143.

Pawlak, M. 2010. „Designing and piloting a tool for the measurement of the use of pronunciation learning strategies". Research in Language 8: 189-202. DOI 10.2478/v10015-010-0005-6.

Pennington, M. 1992. „Reflecting on Teaching and Learning: a developmental focus for the second language classroom" (w:) Perspectives on Second Language Teacher education (red. J. Flowerdew, M. Brock i S. Hsia). Hong Kong: City Polytechnic: 47-65.

Phillips, E. M. 1992. „The effects of language anxiety on student's oral test performance and attitudes". The Modern Language Journal 76: 14-26.

Piechurska-Kuciel, E. 2008. Language anxiety in secondary grammar school students. Opole: Wydawnictwo Uniwersytetu Opolskiego.

Peterson, S. 2000. „Pronunciation Learning Strategies: A First Look”. ERIC Document Reproduction Service No. ED450599 DW 20.11.2013.

Rokoszewska, K. 2012. „The influence of pronunciation learning strategies on mastering English vowels". Studies in Second Language Learning and Teaching 2(3): 391-413.

Schön, D. 1991. The Reflective Practitioner. Aldershot: Ashgate Publishing Ltd.

Spielman, G. and M. L. Radnofsky. 2001. „Learning Language under tension. New directions from a qualitative study". The Modern Language Journal 85: 259-278.

Stanley, C. 1999. „Learning to think, feel and teach reflectivity” (w:) Affect in Language Learning (red. C. Arnold). Cambridge: Cambridge University Press: 109-124.

Szyszka, M. w druku. „Refleksje nad strategiami uczenia się wymowy.” 